\title{
A Triaxial Probe for On-line Proteolysis Coupled with Hydrogen/Deuterium Exchange-Electrospray Mass Spectrometry
}

\author{
Maolian Chen and Kelsey D. Cook \\ Department of Chemistry, University of Tennessee, Knoxville, Tennessee, USA \\ Indu Kheterpal* \\ Center for BioModular Multi-Scale Systems, Louisiana State University, Baton Rouge, Louisiana, USA
}

\author{
Ronald Wetzel ${ }^{+}$ \\ Graduate School of Medicine, University of Tennessee, Knoxville, Tennessee, USA
}

\begin{abstract}
An on-line proteolysis system utilizing a triaxial electrospray probe was developed to aid localization of the hydrogen-bonding interaction sites in hydrogen/deuterium exchange-mass spectrometry (HDX-MS) studies of A $\beta$ (1-40) fibrils. The probe allows delayed introduction of the organic solvent component needed for stable electrospray, thus enhancing hydrolysis performance relative to that of a coaxial probe. Effective on-line digestion was accomplished in $\sim 12 \mathrm{~s}$. The probe should be of general utility for HDX-MS studies of amyloid fibrils and other protein aggregates. (J Am Soc Mass Spectrom 2007, 18, 208-217) () 2007 American Society for Mass Spectrometry
\end{abstract}

$\mathrm{H}$ ydrogen/deuterium exchange (HDX) has been widely used to probe structural and dynamic features of proteins [1-7]. The method exploits the fact that amide protons on the backbone of proteins exchange with solvent protons or deuterons at rates that depend on whether they are involved in hydrogen bonds in secondary structural elements such as $\alpha$ helices and $\beta$-sheets, and/or whether they are sterically shielded from the solvent. Analysis normally involves exposing a protein or noncovalent complex to exchange conditions in a $\mathrm{D}_{2} \mathrm{O}$-based buffer solution, followed by measuring the incorporation of deuterium using methods such as magnetic resonance [1-2], infrared spectrometry [3-4], or mass spectrometry (MS) [5-7]. HDX-MS is well-suited to analysis of relatively large and soluble proteins and to protein mixtures [5-7].

The measured mass shift upon deuteration in HDX-MS analysis provides insight into the overall exchange protection of the entire protein molecule. Determination of specific exposed and protected sites by HDX-MS requires coupling with proteolysis $[6,8]$ and/or tandem mass spectrometry (MS/MS) [9], gen-

Published online October 30, 2006

Address reprint requests to Dr. K. D. Cook, Department of Chemistry, University of Tennessee, Knoxville, TN 37996-1600, USA. E-mail: kcook@utk.edu

* Current address: Pennington Biomedical Research Center, Louisiana State University System, Baton Rouge, LA, USA.

+ Current address: Department of Structural Biology, Pittsburgh Institute for Neurodegenerative Diseases, University of Pittsburgh School of Medicine, Pittsburgh, PA, USA. erally with collision-induced dissociation (CID) or (more recently) electron capture dissociation (ECD) [10]. There is some risk of intramolecular scrambling of deuterium labels during CID [11, 12] or ECD [13]. Peptide digestion can offer an alternative or supplement to direct CID or ECD for localizing incorporated deuterium ${ }^{\circ}$ with $^{\circ} \mathrm{HDX}^{\mathrm{MS}} .^{\circ}$ Pepsin $^{\circ}$ has $^{\circ}$ proven $^{\circ}$ to ${ }^{\circ}$ be particularly useful for this purpose because of its good activity at the low $\mathrm{pH}$ values used to minimize artifactual hydrogen exchange (spurious incorporation or loss of deuterium) during sample work-up after exchange. A typical protocol involves incubation of deuteriumlabeled proteins with pepsin at about $\mathrm{pH} 2$ for $\sim 5 \mathrm{~min}$ at $0{ }^{\circ} \mathrm{C}$ (low-temperature also reduces artifactual exchange). The digest is then subjected to liquid chromatography (LC), with on-line MS or MS/MS analysis to assess the deuterium content of individual digestion products ${ }^{\circ}\left[3-5,{ }^{\circ} 8\right] .{ }^{\circ}$ Relatively $^{\circ}{ }$ high $^{\circ}$ quantities $^{\circ}$ of ${ }^{\circ}$ pepsin are used to minimize digestion time and the corresponding opportunity for scrambling; this can complicate direct analysis of the hydrolysate without LC separation $^{\circ}\left(\right.$ due $^{\circ}$ to $^{\circ}$ increased $^{\circ}$ background $^{\circ}[14]^{\circ}{ }^{\circ}$ Use $^{\circ}$ of an immobilized enzyme in a continuous flow column can $^{\circ}$ mitigate ${ }^{\circ}$ these ${ }^{\circ}$ problems ${ }^{\circ}\left[14^{\circ}-16\right]$.

We have adapted electrospray HDX-MS methodologies for analysis of the $\mathrm{A} \beta$ amyloid fibrils associated with $^{\circ}$ Alzheimer's ${ }^{\circ}$ disease ${ }^{\circ}[17-19] .{ }^{\circ}$ To $^{\circ}$ dissolve ${ }^{\circ}$ fibrils after deuteration and before MS analysis while limiting artifactual exchange, we have used continuous flow mixing of the deuterated fibril suspension with a 
low-pH dissolving solvent that contains acetonitrile $(\mathrm{MeCN})$ to facilitate electrospray and to reduce artifactual exchange (by reducing the protic solvent concentration in the final mix). Using this approach, we have determined that roughly half of the $39 \mathrm{~A} \beta$ (1-40) amide protons are protected from HDX in fibrils grown from the ${ }^{\circ}$ peptide ${ }^{\circ}\left[17,{ }^{\circ} 18\right] .^{\circ}$ In ${ }^{\circ}$ anticipation ${ }^{\circ}$ of $^{\circ}$ efforts ${ }^{\circ}$ to $^{\circ}$ further localize the protected sites, we needed a way to achieve rapid proteolysis with minimal scrambling. Use of an immobilized enzyme would require fibril dissolution before passing through an enzyme column; a faster sample treatment protocol would be desirable. We demonstrate here the utility of a triaxial electrospray probe to facilitate effective and rapid on-line dissolution and proteolysis of fibrils at room temperature. The performance is compared with that of the coaxial probe used $^{\circ}$ previously $\left[17,{ }^{\circ} 18\right]$.

\section{Experimental}

\section{Materials}

HPLC-grade acetonitrile (MeCN) and water were purchased from Fisher Scientific (Pittsburgh, PA). Trifluoroacetic acid (TFA) was purchased from Pierce Biotechnology Inc. (Rockford, IL). Deuterium oxide (100.0 atom \%D) was purchased from Aldrich Chemical Co. (Milwaukee, WI). Neurotensin, concentrated $\mathrm{HCl}$, reagent-grade formic acid (95\% in water), tris(hydroxymethyl)aminomethane (tris), and porcine pepsin were obtained from Sigma Chemical (St. Louis, MO). Triethylamine was obtained from Acros (Pittsburgh, PA) and was distilled before use. All other reagents were used as received. Stock solutions of pepsin were prepared daily at a concentration of 2 $\mu \mathrm{g} / \mu \mathrm{L}$ in $0.01 \mathrm{M} \mathrm{HCl}$. Working solutions were prepared by dilution of the stock solution with appropriate amounts of water, $\mathrm{MeCN}$, and/or formic acid to generate solutions with final composition consistent with the desired MS processing solvent. Nitrogen gas for electrospray experiments was obtained from liquid boil-off.

\section{Sample Preparation}

$\mathrm{A} \beta$ fibrils were grown in phosphate buffer from chemically synthesized A $\beta$ (1-40) peptide (Keck Biotechnology Center, Yale University, New Haven, CT) according $^{\circ}$ to ${ }^{\circ}$ the ${ }^{\circ}$ protocol $^{\circ}$ described ${ }^{\circ}$ previously $^{\circ}$ [17]. ${ }^{\circ}$ Fibril growth was monitored by thioflavin $\mathrm{T}$ fluorescence and the quality of fibrils was confirmed by electron microscopy. To remove the phosphate buffer before MS analysis, fibrils were collected by centrifugation (Eppendorf Centrifuge 5415C, Brinkmann Instruments, Inc., Westbury, NY) at 14,000 rpm for $30 \mathrm{~min}$. After decanting and discarding the supernatant buffer, the fibrils were washed once with $2.0 \mathrm{mM}$ tris. $\mathrm{HCl}$ or tris. $\mathrm{DCl}$ buffer $(\mathrm{pH} 7.5)$, and then recentrifuged, decanted, and resuspended in fresh tris buffer. Monomer samples were dissolved directly in tris buffer. Fibril and monomer samples were prepared at equivalent monomer concentrations between 5 and $42 \mu \mathrm{M}$, as noted.

To assess the effect of acetonitrile on pepsin activity, $\mathrm{A} \beta$ monomer solution in $2 \mathrm{mM}$ tris was digested with freshly-made pepsin solutions in the presence of water, $0.5 \%$ formic acid, and varying amounts of $\operatorname{MeCN}(0,15$, $30,50 \% \mathrm{vol} / \mathrm{vol})$. Solutions also contained 0 or 0.06 $\mathrm{mg} / \mathrm{ml}(\sim 14 \mu \mathrm{M}) \mathrm{A} \beta$ monomer and 0 or $1.2 \mathrm{mg} / \mathrm{ml}$ pepsin (providing a 20:1 wt/wt pepsin: $\mathrm{A} \beta$ ratio, or roughly a $2.5: 1$ mol ratio, when both are present). To mimic the timing of the on-line experiments, solutions containing pepsin were generally mixed in an Eppendorf vial using a vortex mixer so as to minimize reaction time; $\sim 20 \mathrm{~s}$ was the minimum practical reaction time. The digestions were quenched by adding sufficient 0.2 $\mathrm{M}$ ammonium hydroxide to bring the final solution to $\mathrm{pH}$ around 8. Following quenching, $100-\mu \mathrm{L}$ aliquots were analyzed by HPLC and HPLC/MS (details below). The retention time of $\mathrm{A} \beta$ was around $15.0 \mathrm{~min}$. Hydrolysis products eluted in the range of 8 to $16 \mathrm{~min}$.

\section{High Performance Liquid Chromatography}

Reversed-phase HPLC and LC-MS experiments were conducted with an Agilent 1100 Series LC/MSD system (Wilmington, DE) with a ZORBAX SB-C3 column (pore size: $5 \mu \mathrm{m}$, diameter: $3 \mathrm{~mm}$, length: $150 \mathrm{~mm}$ ), an autosampler, serial UV and electrospray MS detectors, and a splitter (splitting ratio: 100:1). The solvent flow rate was $1 \mathrm{~mL} / \mathrm{min}$, and the temperature was controlled at $25{ }^{\circ} \mathrm{C}$. The solvents used were $0.1 \%$ formic acid in water (Solvent A) and $0.1 \%$ formic acid in $\mathrm{MeCN}$ (Solvent B). The column equilibrated to $1 \%$ Solvent B before injection, and then the sample was eluted with a linear gradient of 1 to $51 \%$ Solvent B over a $40 \mathrm{~min}$ period. The separation was monitored by absorbance at $215 \mathrm{~nm}$ and by MS scans from $\mathrm{m} / \mathrm{z} 300$ to 2000 .

The LC-MS experiments employed the electrospray source operating in the positive ion mode. The drying gas flow $\left(\mathrm{N}_{2}\right)$, nebulizer pressure $\left(\mathrm{N}_{2}\right)$, drying temperature, and capillary voltage were set at $3 \mathrm{~L} / \mathrm{min}, 35$ psig, $300{ }^{\circ} \mathrm{C}$, and $3000 \mathrm{~V}$, respectively.

\section{Electrospray Ionization MS}

A Q-Star XL quadrupole time-of-flight hybrid instrument (Applied Biosystems, Foster City, CA) equipped with an IonSpray source was used to acquire electrospray ionization (ESI) MS and MS/MS spectra not involving LC. All experiments were performed in the positive ion mode. Source parameters including the sprayer position were optimized for high sensitivity and stability. The IonSpray voltage and declustering potential were 4500 and $60 \mathrm{~V}$, respectively. Except as noted, the sprayer tip was positioned about $12 \mathrm{~mm}$ away from the curtain plate with a lateral displacement about $5 \mathrm{~mm}$ off-axis at an angle of $45^{\circ}$ to the ion sampling orifice. A microammeter (Simpson Electric Co., Chicago, IL) was connected between the high voltage power supply and the ion source connector to 


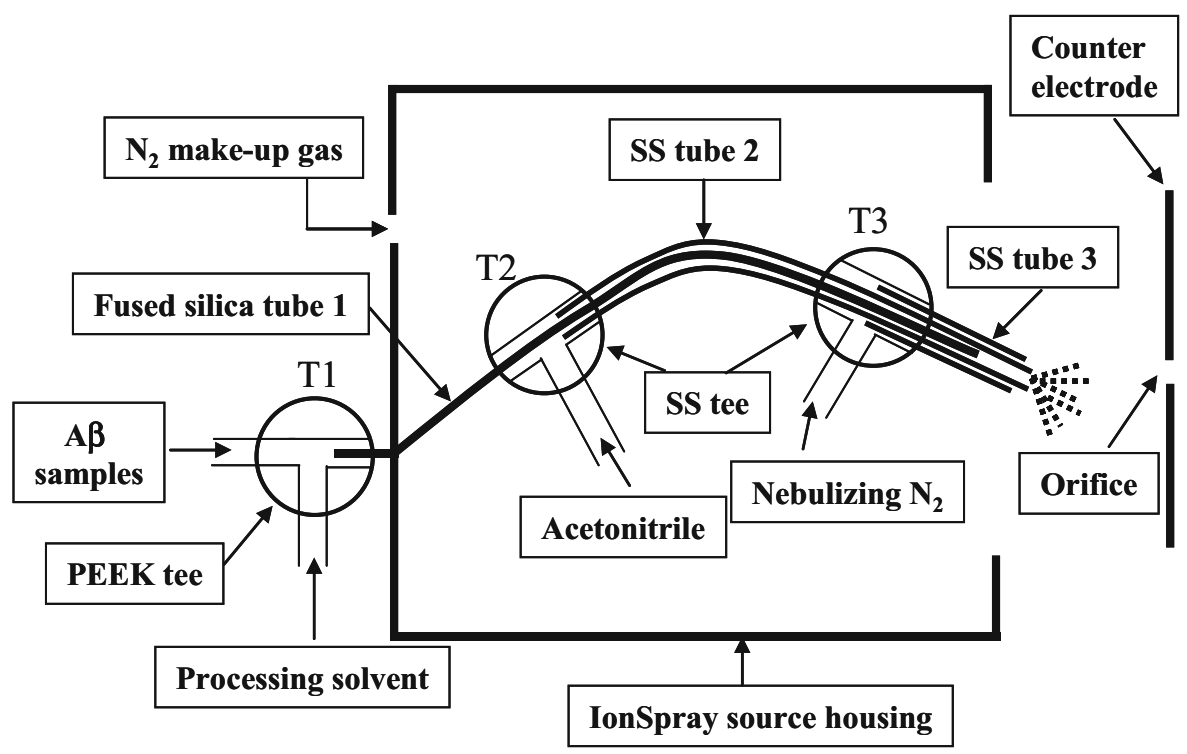

Figure 1. Diagram of the modified electrospray probe (not to scale), shown in the triaxial configuration. For coaxial operation, tube 1 is extended flush with the end of stainless steel (ss) tube 2.

enable monitoring of the emission current. Nitrogen was used as nebulizer, curtain, and collision gas. The pressures of nebulizer and curtain gases were, respectively, 40 and $25 \mathrm{psi}$, while the gas pressure in the collision cell was set at three arbitrary units for the MS mode and five for the MS/MS mode. Mass spectra were acquired in the multichannel accumulation mode from $\mathrm{m} / \mathrm{z} 392$ to 1200 for 1 $\mathrm{min}$, unless otherwise specified. MS/MS spectra were acquired using a $3 \mathrm{Da}$ window for MS1 and collecting data from MS2 over the range 100 to $2000 \mathrm{~m} / \mathrm{z}$ for $10 \mathrm{~min}$. To minimize artifactual deuterium exchange, the hole from the source leading to the venturi pump was blocked so that moist laboratory air was prevented from being sucked into the source housing. Also, extra nitrogen gas ( $500 \mathrm{~mL} / \mathrm{min}$ ) was introduced into the source through the "make-up" hole on the IonSpray source housing.

The IonSpray probe includes two stainless steel microvolume $^{\circ}$ tees $^{\circ}\left(\right.$ Figure $\left.^{\circ} 1\right){ }^{\circ}{ }^{\circ}$ The $^{\circ}$ tee ${ }^{\circ}$ nearer ${ }^{\circ}$ the ${ }^{\circ}$ spray tip (T3) is used to introduce nebulizing gas via stainless steel tube 3, while the other tee (T2) can be used to provide a continuous stream of sample via tube 2. A third tee (T1; 0.25-mm diameter PEEK; Valco Instruments, Houston, TX) was added to enable on-line addition of processing solvent. In practice, an incubating HDX sample is mixed with processing solvent in T1 by infusion via separate $100-\mu \mathrm{m}$ i.d. fused silica capillaries (Polymicro Technologies, Phoenix, AZ) using the built-in and Harvard Apparatus (South Natick, MA) model 11 syringe pumps, respectively. The resulting mixture flowed through the fused silica tube $1(75 \mu \mathrm{m}$ i.d. $\times 190 \mu \mathrm{m}$ o.d.) past T2 to the spray tip.

The probe was operated in two modes. In the standard ("coaxial") mode, the spray end of tube 1 was flush with the end of the stainless steel tube $2(220 \mu \mathrm{m}$ i.d. $\times 410 \mu \mathrm{m}$ o.d.) and the third arm of T2 was unused (so that tube 2 was left open to air). In the "triaxial mode", tube 1 was retracted slightly $(\sim 5 \mathrm{~mm})$ from the spray end of tube 2 , thus providing a small volume $(\sim 0.2 \mu \mathrm{L})$ for mixing with a secondary solvent that was delivered from $\mathrm{T} 2$ via tube 2 using a Harvard Model 22 syringe pump. Note that mixing does not occur within T2, but only when the two solutions reach the probe tip. For simplicity and convenience, "coaxial probe" and "triaxial probe" are the terms used for describing the two configurations in the following discussion.

When the Ionspray probe was used as a coaxial probe, flow rates for $\mathrm{A} \beta$ sample solution and processing solvent (generally 46/54/0.5 (vol/vol/vol) $\mathrm{H}_{2} \mathrm{O} /$ $\mathrm{MeCN} / \mathrm{HCOOH}$ ) were $0.85 \mu \mathrm{L} / \mathrm{min}$ and $9.25 \mu \mathrm{L} / \mathrm{min}$, respectively. For analysis using the triaxial probe, sample $(0.85 \mu \mathrm{L} / \mathrm{min})$ was mixed with the initial processing solvent (generally $0.5 \%$ formic acid in water, $4.25 \mu \mathrm{L} /$ $\mathrm{min}$ ) in $\mathrm{T} 1$ and then mixed with $\mathrm{MeCN}$ (containing $0.5 \%$ formic acid, $5 \mu \mathrm{L} / \mathrm{min}$ ) at the probe tip. The total flow through tube 1 was twice as high in the coaxial probe, so the length of tube 1 was doubled (46 cm versus 23 $\mathrm{cm}$ ) in the coaxial probe, to match the total time from mixing to the end of tube $1(\sim 12 \mathrm{~s})$. With the triaxial probe, there was an additional $1.1 \mathrm{~s}$ transit time for the $0.2-\mu \mathrm{L}$ volume after tube 1 . Electrical contact was made at T2, making tube 2 the anodic emitter.

Calculation of average molecular weights was done using the equation

$$
\mathrm{MW}_{\mathrm{avg}}=\frac{\sum_{n}\left(I_{n} \times M_{n}\right)}{\sum_{n} I_{n}}
$$

where $I_{n}$ is the intensity (height) of $n_{\text {th }}$ isotopic peak and $M_{n}$ is the centroid mass of that peak (corrected for ionizing protons). For ions detected with multiple charge states, 

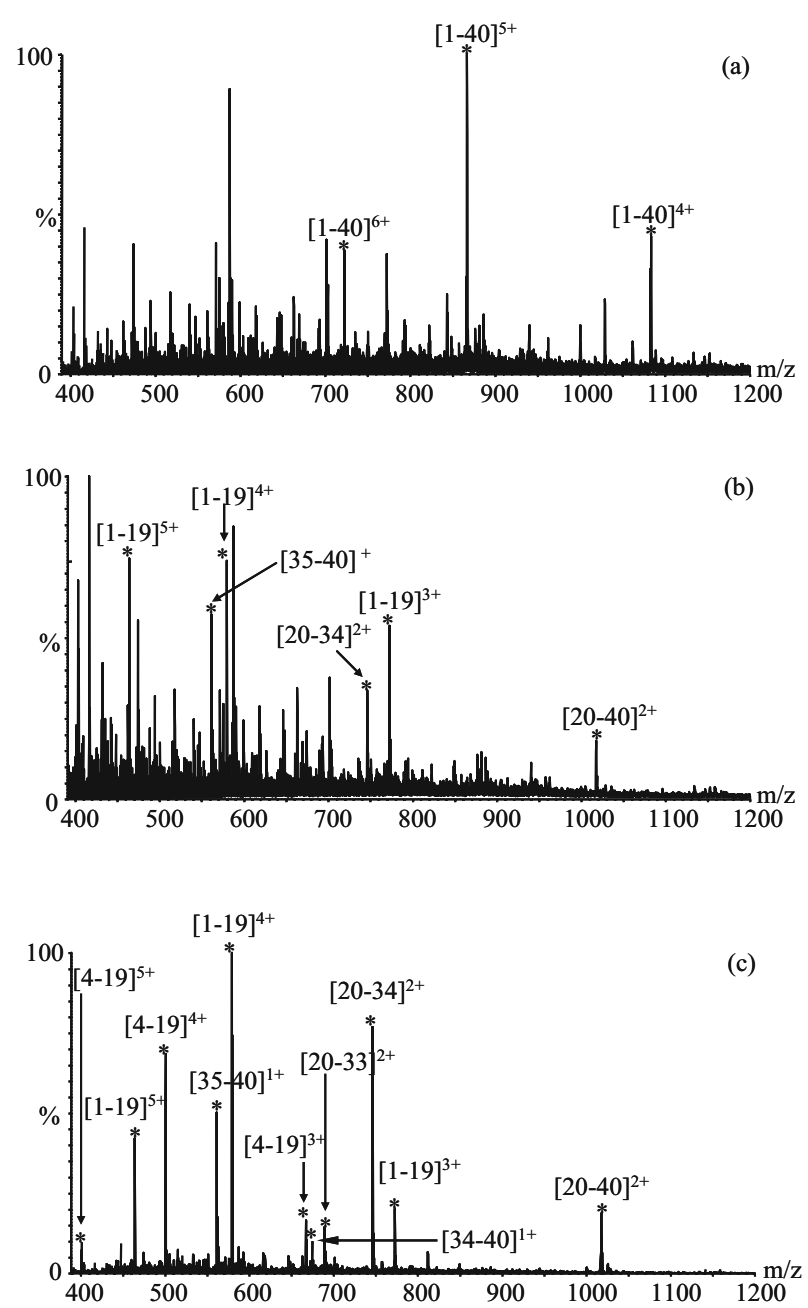

Figure 2. ESI mass spectra obtained from on-line digestion of $\mathrm{A} \beta$ monomers with pepsin (a) in 50/50/0.5 ( vol/vol/vol) $\mathrm{H}_{2} \mathrm{O} /$ $\mathrm{MeCN} / \mathrm{HCOOH}$ using a coaxial probe (enzyme/peptide $=40 / 1$ [wt/wt]); (b) in 85/15/0.5 (vol/vol/vol) $\mathrm{H}_{2} \mathrm{O} / \mathrm{MeCN} / \mathrm{HCOOH}$ using a coaxial probe (enzyme/peptide $=43 / 1$ [wt/wt]); (c) in $100 / 0.5$ (vol/vol) $\mathrm{H}_{2} \mathrm{O} / \mathrm{HCOOH}$ using a triaxial probe (enzyme/ peptide $=0.9 / 1[\mathrm{wt} / \mathrm{wt}])$. Intact peptide and digestion products are labeled and marked with asterisks; unlabeled peaks are from pepsin and solvent background.

neutral molecular masses obtained from those charge states were averaged to obtain the molecular masses.

Protein Prospector 4.0.5 software (University of California, San Francisco, CA) was used to identify possible matches for peptic fragments from the $\mathrm{A} \beta$ primary sequence, which were then confirmed using MS/MS with collision energies between 30 and $45 \mathrm{eV}$ (as needed for adequate dissociation of a given fragment).

\section{Results and Discussion}

Conditions for On-Line Proteolysis

Using a Coaxial Probe: The Effect of Acetonitrile on Pepsin Activity

Given the compatibility of pepsin with low $\mathrm{pH}$ and the occasional enhancement of enzyme activity by organic solvents ${ }^{\circ}\left[20,{ }^{\circ} 21\right]^{\circ}$, the $^{\circ}$ simplest $^{\circ}$ approach $^{\circ}$ to ${ }^{\circ}$ on-line proteolysis of fibril-derived $\mathrm{A} \beta$ would be to add pepsin to the processing solvent used to arrest $\mathrm{H} / \mathrm{D}$ exchange, dissolve ${ }^{\circ}$ the ${ }^{\circ}$ fibrils, ${ }^{\circ}$ and ${ }^{\circ}$ facilitate ${ }^{\circ}$ ESI. ${ }^{\circ}$ Figure $^{\circ} 2 a^{\circ}$ illustrates the results obtained using this simple approach with $\mathrm{A} \beta$ monomer. There is no evidence of pepsin digestion of $\mathrm{A} \beta$ even at an enzyme:monomer weight ratio as high as $40: 1$, using the $50 / 50 / 0.5(\mathrm{vol} / \mathrm{vol} / \mathrm{vol})$ $\mathrm{H}_{2} \mathrm{O} / \mathrm{MeCN} / \mathrm{HCOOH}$ processing solvent used previously $^{\circ}$ for $^{\circ}$ fibril $^{\circ}$ analysis $^{\circ}$ without $^{\circ}$ proteolysis $^{\circ}\left[17,{ }^{\circ} 18\right]$. Only intact $\mathrm{A} \beta$ is detected (labeled peaks); all other peaks above noise were attributable to solvent and/or pepsin background. Similar results (not shown) were obtained with the digestion of $\mathrm{A} \beta$ fibrils at the same weight ratio. There are two possible explanations for these observations: either the enzyme is inactive under these conditions, or the signals due to proteolysis products $^{\circ}$ are $^{\circ}$ suppressed $^{\circ}[22]^{\circ}$ (e.g., ${ }^{\circ}$ by $^{\circ}$ more $^{\circ}$ hydrophobic intact material).

To distinguish between these possibilities, digests with varying $\mathrm{MeCN}$ concentrations were analyzed by HPLC using UV and MS detection. In the first control experiments, pepsin was omitted, allowing determination of the chromatographic retention time of the intact $\mathrm{A} \beta$ monomer. In the absence of pepsin, the monomer peak was detectable with roughly constant sensitivity and retention time $(15.0 \mathrm{~min})$ for all digestion solvents tested. Upon addition of pepsin (20:1 wt/wt pepsin: $\mathrm{A} \beta$ ), incubation for $20 \mathrm{~s}$ (approximating the time available for on-line digestion using the coaxial probe) and quenching with $\mathrm{NH}_{4} \mathrm{OH}$, the monomer peak disappeared if the solvent contained 0 to $30 \% \mathrm{MeCN}$, indicating effective hydrolysis. Representative LC-UV and LC-MS ${ }^{\circ}$ chromatograms ${ }^{\circ}$ are $^{\circ}$ shown ${ }^{\circ}{ }^{\circ}{ }^{\circ}$ Figure $^{\circ} 3 . .^{\circ}$ At $^{\circ} 50 \%$ $\mathrm{MeCN}$, pepsin only attenuated the monomer peak to about $31 \%$ of the peak area observed when pepsin was absent, indicating significant inhibition of enzyme ac-

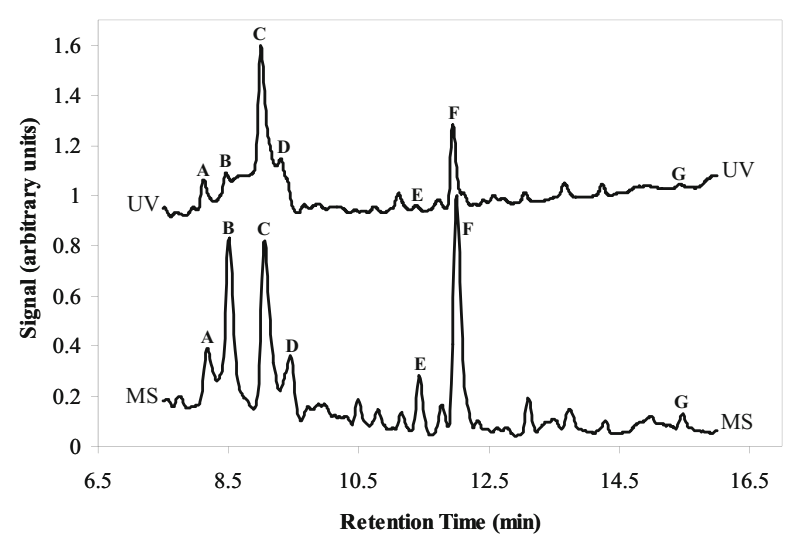

Figure 3. LC-UV and LC-MS chromatograms obtained from digestion of $\mathrm{A} \beta$ monomers for $20 \mathrm{~s}$ using pepsin in 100/0.5 (vol/vol) $\mathrm{H}_{2} \mathrm{O} / \mathrm{HCOOH}$ (enzyme/peptide $=20 / 1$ [wt $\left./ \mathrm{wt}\right]$ ). The UV curve is shifted upwards by 0.6 arbitrary units. Observed peptide fragments are labeled: A (4-19), B (35-40), C (1-19), D (20-33), E (34-40), F (20-34), and G (20-40). Unlabeled peaks may be associated with pepsin or sample and are not identified. 
Table 1. Fragments of the $A \beta$ sequence (numbers in brackets refer to residues included in the fragment) observed by LC following digestion of monomer with pepsin (20 s digestion time, enzyme:substrate $=20: 1 \mathrm{w} / \mathrm{w}$, except where noted) in the solvents indicated. Also listed are the observed LC retention times and peak areas. Fragment assignments were confirmed by MS/MS. Indicated uncertainties are based on the standard deviation of triplicate LC-UV measurements

\begin{tabular}{|c|c|c|c|c|c|}
\hline \multirow[b]{3}{*}{ Fragment } & \multirow{3}{*}{$\begin{array}{l}\text { Retention time } \\
(\text { min) }\end{array}$} & \multicolumn{4}{|c|}{ Solvent composition $\left(\mathrm{H}_{2} \mathrm{O}: \mathrm{MeCN}: \mathrm{HCOOH}\right)(\mathrm{vol} / \mathrm{vol} / \mathrm{vol})$} \\
\hline & & $100: 0: 0.5$ & $85: 15: 0.5$ & $70: 30: 0.5$ & $50: 50: 0.5$ \\
\hline & & \multicolumn{4}{|c|}{ UV area (arbitrary units) } \\
\hline [4-19] & 8.2 & $128 \pm 6$ & 0 & 0 & 0 \\
\hline [35-40] & 8.5 & $62 \pm 2$ & $93 \pm 4$ & $76 \pm 15$ & $9 \pm 2$ \\
\hline [1-19] & 9.0 & $638 \pm 13$ & $994 \pm 19$ & $970 \pm 47$ & $257 \pm 54$ \\
\hline [20-33] & 9.3 & $110 \pm 7$ & $48 \pm 3$ & $28 \pm 4$ & 0 \\
\hline [34-40] & 11.4 & $20.0 \pm 0.4$ & $46 \pm 2$ & $14 \pm 2$ & 0 \\
\hline [20-34] & 12.1 & $387 \pm 3$ & $359 \pm 4$ & $266 \pm 23$ & $14 \pm 6$ \\
\hline [20-40] & 15.4 & $12 \pm 3$ & $27 \pm 5$ & $138 \pm 23$ & $145 \pm 24$ \\
\hline [1-40] & 15.0 & 0 & 0 & 0 & $468 \pm 12$ \\
\hline$[1-40]^{a}$ & 15.0 & - & - & - & $1531 \pm 26$ \\
\hline$[1-40]^{\mathrm{b}}$ & 15.0 & - & - & - & $1439 \pm 27$ \\
\hline$[1-40]^{\mathrm{c}}$ & 15.0 & - & - & - & $1179 \pm 30$ \\
\hline
\end{tabular}

${ }^{a}$ Digestion for $20 \mathrm{~s}$ with an enzyme:substrate $[\mathrm{w} / \mathrm{w}]$ ratio of 2:1.

${ }^{b}$ Digestion for $60 \mathrm{~s}$ with an enzyme:substrate [w/w] ratio of 2:1.

${ }^{c}$ Digestion for 5 min with an enzyme:substrate $[\mathrm{w} / \mathrm{w}]$ ratio of 2:1.

tivity $^{\circ}\left(\right.$ Table $\left.^{\circ} 1\right) .^{\circ}$ When $^{\circ}$ the $^{\circ}$ amount $^{\circ}$ of ${ }^{\circ}$ enzyme $^{\circ}$ was reduced to $2: 1(\mathrm{wt} / \mathrm{wt}$ ) with $50 \% \mathrm{MeCN}$, the intensity of the monomer was not attenuated measurably unless the mixing time was increased substantially; after 1 min of digestion, the signal for intact peptide was attenuated by $6 \%$, and 5 min digestion resulted in $23 \%$ attenuation.

In addition to the attenuation of the peak for the intact peptide, enzyme activity was evidenced by the appearance of new peaks in the HPLC experiments. With the MS detector it was possible to confirm that these $^{\circ}$ arose $^{\circ}$ from $^{\circ}$ proteolytic $^{\circ} \mathrm{A} \beta^{\circ}$ fragments $^{\circ}\left(\right.$ Table $\left.^{\circ} 1\right)$. The prominence of fragment 1-19 (resulting from cleavage between $P_{h}{ }_{19}$ and $P e_{20}$ ) is consistent with the known preference of pepsin for cleavage of Phe-Phe bonds ${ }^{\circ}[23] . .^{\circ}$ The $^{\circ}$ complementary $^{\circ} 20-40^{\circ}$ fragment ${ }^{\circ}$ grows with increasing $\mathrm{MeCN}$ concentration, at the expense of smaller fragments, which result from cleavage between $\mathrm{Leu}_{34}$ and $\mathrm{Met}_{35}$, and between Gly ${ }_{33}$ and $\mathrm{Leu}_{34}$, presumably after the $\mathrm{Phe}_{19} / \mathrm{Phe}_{20}$ cleavage. This and the overall inhibition of enzyme activity in the presence of $\mathrm{MeCN}$ are consistent with the reported effect of organic solvents, ${ }^{\circ}$ including ${ }^{\circ} \mathrm{MeCN}^{\circ}\left[16,{ }^{\circ} 24^{\circ}-26\right],{ }^{\circ}$ on ${ }^{\circ}$ pepsin ${ }^{\circ}$ activity. As ${ }^{\circ}$ evident ${ }^{\circ}$ from Figure 4 , the ${ }^{\circ}$ seven ${ }^{\circ}$ fragments ${ }^{\circ}$ bserved are consistent with the preferences of the relatively nonspecific proteolysis by pepsin (cleavages on the $\mathrm{N}$ and/or C-terminal side of Phe (F), Leu (L), Glu (E), Trp (W), ${ }^{\circ}$ and $\left.^{\circ} \operatorname{Tyr}^{\circ}(Y)^{\circ}\left[23,{ }^{\circ} 27\right]\right)$.

Based on the LC results, a preliminary on-line experiment was attempted using $30 \% \mathrm{MeCN}$ and an enzyme:A $\beta$ ratio of 20:1 [wt/wt]. Relatively little hydrolysis plus a strong background similar to that shown in Figure $2 a^{\circ}{ }^{\circ}$ were ${ }^{\circ}$ detected, ${ }^{\circ}$ possibly $^{\circ}$ due ${ }^{\circ}$ to ${ }^{\circ}$ the ${ }^{\circ}$ shorter $^{\circ}(12$ $\mathrm{s}$ versus $20 \mathrm{~s}$ for the LC experiments) reaction time and suppression of signal by autolysis products (data not shown). Given the necessity for some $\mathrm{MeCN}$ to assure stable $^{\circ}$ spray $^{\circ}\left[22,{ }^{\circ} 28,{ }^{\circ} 29\right],{ }^{\circ} 15 \%{ }^{\circ} \mathrm{MeCN}^{\circ}$ was $^{\circ}$ selected $^{\circ}$ as $^{\circ} \mathrm{a}$ reasonable compromise between acceptable signal and retention of enzyme activity. Even under these conditions (85/15/0.5 $\left.\mathrm{H}_{2} \mathrm{O} / \mathrm{MeCN} / \mathrm{HCOOH}\right)$, a high enzyme concentration (roughly 43:1 wt/wt enzyme:A $\beta$ ) was needed to fully attenuate the signal from intact peptide during on-line digestion of $15-\mu \mathrm{M}$ monomer samples, and roughly 110:1 was needed for $16-\mu \mathrm{M}$ (equivalent monomer concentration) fibrils. The higher pepsin ${ }^{\circ}$ requirement ${ }^{\circ}$ for ${ }^{\circ}$ fibrils ${ }^{\circ}$ likely ${ }^{\circ}$ reflects ${ }^{\circ}$ the ${ }^{\circ}$ shorter time available for hydrolysis due to the finite time needed to dissolve the fibrils and to expose cleavable sites. Under these extreme conditions, hydrolysis products $^{\circ}$ were ${ }^{\circ}$ detectable (Figure $2 \mathrm{~b}$ ). ${ }^{\circ}$ However, ${ }^{\circ}$ at ${ }^{\circ}$ such high enzyme concentrations, autolysis of pepsin can become a significant competing reaction, leading to a strong background $^{\circ}$ (Figure $2 \mathrm{~b}$ ). ${ }^{\circ}$ Furthermore, ${ }^{\circ}{ }^{\circ}$ the $^{\circ}$ absence $^{\circ}$ of pepsin, the signal-to-background ratio (S/B) (background assessed as the average intensity between $\mathrm{m} / \mathrm{z}$ 1100 and $m / z$ 1200) for the $5+$ charge state base peak for the intact $\mathrm{A} \beta$ monomer using $15 \% \mathrm{MeCN}$ was around

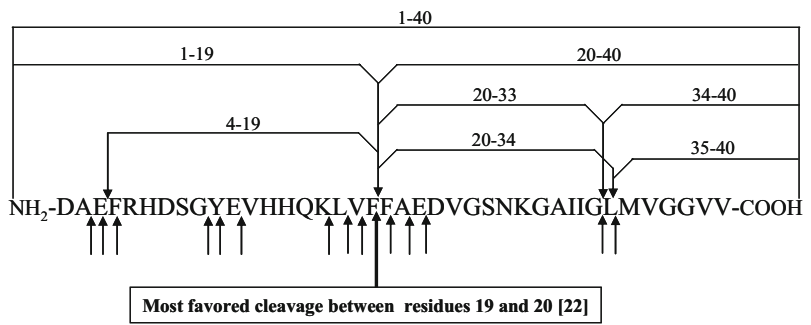

Figure 4. Comparison of the favored and observed pepsin cleavage sites on the $\mathrm{A} \beta$ peptide. The down arrows represent the experimentally observed cleavage sites during $12 \mathrm{~s}$ digestion using a triaxial probe, while the up arrows indicate the cleavage sites expected to be preferred by pepsin. Phe (F)-Phe $(\mathrm{F})$ cleavage is especially favorable. 
half that obtained using $50 \% \mathrm{MeCN}$. Thus, such an on-line digestion system is far from being ideal.

\section{On-Line Proteolysis Using a Triaxial Probe}

The $^{\circ}$ triaxial ${ }^{\circ}$ probe $^{\circ}$ pictured $^{\circ}$ in ${ }^{\circ}$ Figure $^{\circ} 1^{\circ}$ was $^{\circ}$ used ${ }^{\circ}$ to allow separate optimization of proteolysis and electrospray conditions by delaying introduction of $\mathrm{MeCN}$ until just before spraying. With the triaxial probe, only a 0.9:1 (wt/wt) pepsin: $\mathrm{A} \beta$ was required to reduce the monomer signal from $15 \mu \mathrm{M} \mathrm{A} \beta$ to baseline versus $43: 1$ with the coaxial probe; the final solvent composition was $50.5 / 49.5 / 0.46 \mathrm{H}_{2} \mathrm{O} / \mathrm{MeCN} / \mathrm{HCOOH}$ for the triaxial probe (versus 86.3/13.7/0.46 $\mathrm{H}_{2} \mathrm{O} / \mathrm{MeCN}$ / $\mathrm{HCOOH}$ for hydrolysis with the coaxial probe). Moreover, the same seven major $\mathrm{A} \beta$ fragments were observed $^{\circ}\left(\mathrm{S} / N>^{\circ} 70 ;{ }^{\circ} \text { Figure }^{\circ} 2 \mathrm{c}\right)^{\circ}$ as ${ }^{\circ}$ from ${ }^{\circ}$ the ${ }^{\circ}$ bench-top digestion ${ }^{\circ}\left(\right.$ Table $^{\circ}$ ), ${ }^{\circ}$ versus $^{\circ}$ only ${ }^{\circ}$ four ${ }^{\circ}$ fragments ${ }^{\circ}$ (among strong interfering background peaks) using the coaxial probe $^{\circ}\left(\right.$ Figure $\left.^{\circ} 2 \mathrm{~b}\right) .^{\circ}{ }^{\circ}$ The $^{\circ}$ performance ${ }^{\circ}$ for ${ }^{\circ}$ digestion ${ }^{\circ}$ of fibrils $(18 \mu \mathrm{M})$ was also enhanced; the 10.6:1 weight ratio of pepsin: $A \beta$ needed to eliminate the signal from intact fibrillar $\mathrm{A} \beta$ was roughly $1 / 10$ the amount needed using the coaxial probe. Under these conditions the fibrils gave the same fragments as those observed for monomer ${ }^{\circ}{ }^{\circ}$ Figure $^{\circ}$ 2c.

Although some expected cleavages were "missed" in the $^{\circ} 12^{\circ} \mathrm{s}^{\circ}$ digestion $^{\circ}$ time $^{\circ}$ (evident ${ }^{\circ}$ in $^{\circ}$ Figure $^{\circ} 4$ ), ${ }^{\circ}$ the fragments produced have the potential to provide structural information about the N-terminus (1-19), C-terminus (35-40), and part of the protected core $(20-34)^{\circ}\left[30^{\circ}-32\right] .{ }^{\circ} \mathrm{The}^{\circ}$ observed ${ }^{\circ}$ cleavage ${ }^{\circ}$ between ${ }^{\circ}$ positions 19 and 20 for the fibrils is particularly significant, since this site is believed to be involved in the $\beta$-sheet network ${ }^{\circ}\left[30^{\circ}-32\right]^{\circ} ;$ dissolution $^{\circ}$ of ${ }^{\circ}$ fibrils ${ }^{\circ}$ evidently $^{\circ}$ precedes hydrolysis, exposing sites involved in the secondary structures. HDX studies of these peptic fragments should contribute to the testing and refinement of structural ${ }^{\circ}$ models $^{\circ}\left[30^{\circ}-32\right] . .^{\circ}$ Although ${ }^{\circ}$ detailed ${ }^{\circ}$ discussion lies outside the scope of the current study, feasibility of such HDX experiments is considered next.

\section{Triaxial Versus Coaxial Probe for HDX-MS Studies}

To be useful for HDX-MS studies of amyloid fibrils, the triaxial probe must not only provide effective proteolysis, but it must do so without compromising sensitivity, impairing the dissolution of fibrils, or introducing additional artifactual exchange. These figures of merit were assessed in the series of experiments described next.

\section{Sensitivity and Signal Stability}

Similar sensitivity was achieved for both probes, as evidenced by nearly identical base peak $\left([1-40]^{5+}\right.$ at $\mathrm{m} / \mathrm{z}$ 867) absolute intensities $\left[(1.8 \pm 0.06) \times 10^{4}\right.$ for the
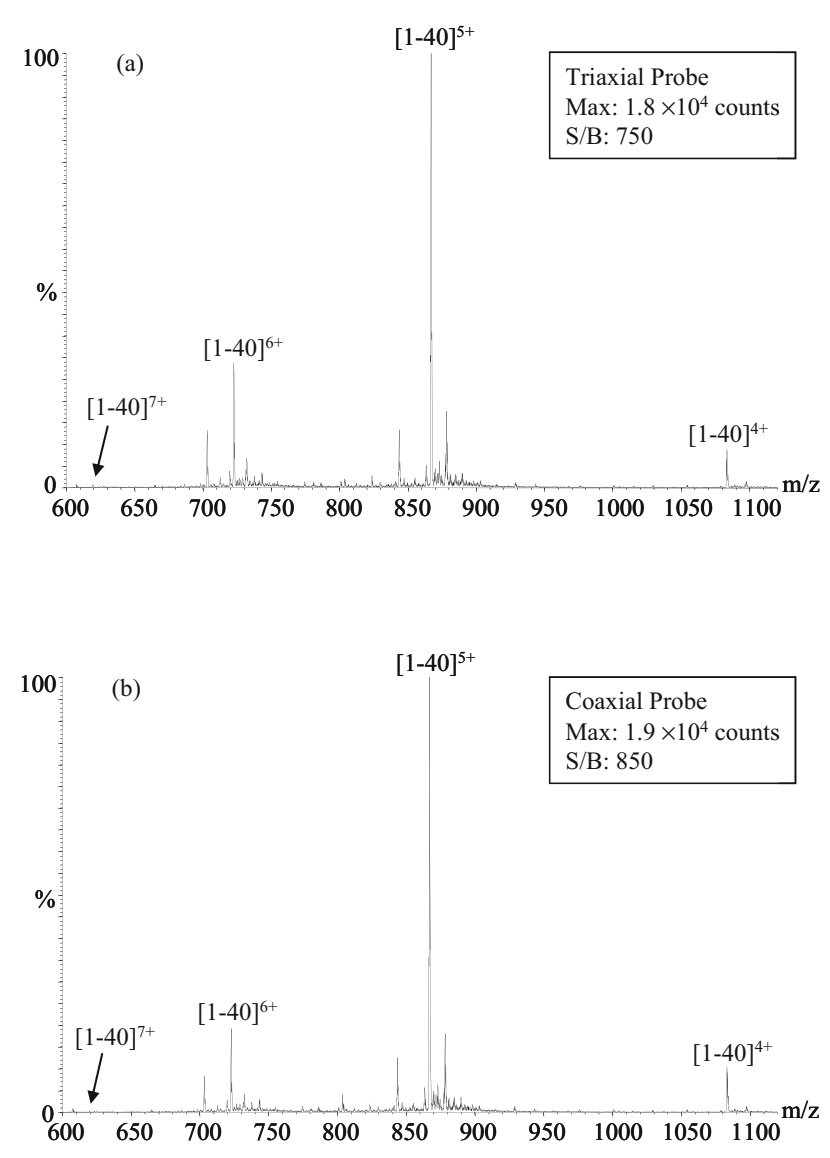

Figure 5. Mass spectra of $\mathrm{A} \beta$ obtained using (a) the triaxial probe and (b) the coaxial probe. The inset shows the absolute intensity (counts) and signal-to-background ratio (S/B) of the highest monoisotopic peak $(\mathrm{m} / \mathrm{z}$ 867) accumulated over a 1-min period. Background was assessed as the average intensity between $\mathrm{m} / \mathrm{z}$ 1100 and $\mathrm{m} / \mathrm{z} 1200$.

triaxial probe, versus $(1.9 \pm 0.04) \times 10^{4}$ for the coaxial probe] and signal-to-background ratios (750 for the triaxial probe, versus 850 for the coaxial probe) for $\mathrm{A} \beta$ monomers run on the two probes under conditions where the final solution composition is identical (50.5/ $\left.49.5 / 0.46 \mathrm{H}_{2} \mathrm{O} / \mathrm{MeCN} / \mathrm{HCOOH}\right)^{\circ}$ (Figure ${ }^{\circ}$ ). ${ }^{\circ}{ }^{T}$ The ${ }^{\circ}$ relative standard deviation (RSD) of the absolute intensity of the base peak from 600 scans averaged over a $10 \mathrm{~min}$ period is also nearly identical for the two probes $(3 \%$ RSD for the triaxial probe versus $2 \%$ for the coaxial probe), suggesting good signal stability for both probes.

It is interesting to note that while the base peaks and overall ${ }^{\circ}$ charge-state ${ }^{\circ}$ distributions ${ }^{\circ}$ in ${ }^{\circ}$ Figure $4 a^{\circ}$ and ${ }^{\circ} \mathrm{b}$ are similar, the relative abundance of the +6 charge state is somewhat higher with the triaxial probe $(29 \% \pm 2 \%$ versus $21 \% \pm 3 \%$ with the coax probe), despite the fact that the emission current was lower $(0.25 \mu \mathrm{A}$, versus 0.5 $\mu \mathrm{A}$ for the coaxial probe) so that the $\mathrm{pH}$ would be expected ${ }^{\circ}$ to ${ }^{\circ}$ be $^{\circ}$ higher $^{\circ}[33-35] .{ }^{\circ}$ This $^{\circ}$ difference $^{\circ}$ was reproducible from scan-to-scan, but sensitive to tuning parameters, ${ }^{\circ}$ as $^{\circ}$ observed ${ }^{\circ}$ elsewhere $\left[36\right.$. $^{\circ}{ }^{\circ}$ One ${ }^{\circ}$ contributing factor could be the difference in spray tip and "electrode" geometries. For the triaxial probe, electrical 


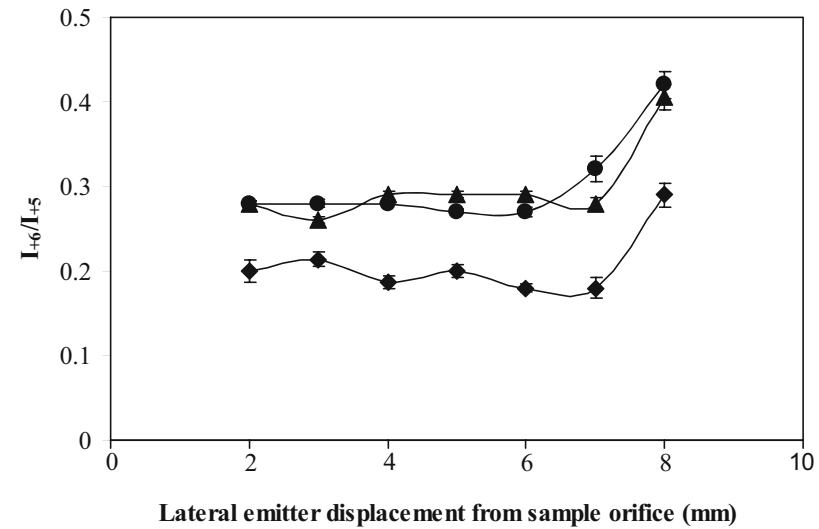

Figure 6. The intensity ratio of the +6 charge state peak to the +5 charge state peak versus the position of the probe tip relative to the sample orifice. Data were obtained from solutions containing $\mathrm{A} \beta$ monomer in 50/50/0.5 (vol/vol/vol) $\mathrm{H}_{2} \mathrm{O} / \mathrm{MeCN} / \mathrm{HCOOH}$ in tube 1 on the coaxial probe (filled diamond); $\mathrm{A} \beta$ monomer in $100 / 0.5$ ( vol/vol) $\mathrm{H}_{2} \mathrm{O} / \mathrm{HCOOH}$ in tube 1 mixed on-line with $100 / 0.5$ (vol/vol) $\mathrm{MeCN} / \mathrm{HCOOH}$ through tube 2 using the triaxial probe (filled triangle); or pre-mixed $\mathrm{A} \beta$ (1-40) monomer with $50 / 50 / 0.5(\mathrm{vol} / \mathrm{vol} / \mathrm{vol}) \mathrm{H}_{2} \mathrm{O} / \mathrm{MeCN} / \mathrm{HCOOH}$ in both tube 1 and tube 2 on the triaxial probe (filled circle). The axial displacement was fixed at $12 \mathrm{~mm}$. At $0 \mathrm{~mm}$, the probe tip is on-axis with the sample orifice. Error bars represent the standard deviation of ratios from triplicate mass spectra.

contact is made at least $\sim 5 \mathrm{~mm}$ from the sprayer tip, whereas for the coaxial probe the contact is made only when the liquid from the silica tube 1 wets the steel tube 2 near the emitter tip. Other possible contributors include space charging and mixing efficiency, which are considered next.

\section{Space Charge Effect}

To $^{\circ}$ test $^{\circ}$ for $^{\circ}$ contributions $^{\circ}$ from $^{\circ}$ space $^{\circ}$ charge $^{\circ}$ effects $^{\circ}[37$, $38]^{\circ}$ to $0^{\circ}$ the ${ }^{\circ}$ enhancement ${ }^{\circ}$ of $f^{\circ}$ the ${ }^{\circ} 6+^{\circ}$ peak $^{\circ}$ in ${ }^{\circ}$ Figure 5 , ${ }^{\circ}$ the relative intensities of the +6 and +5 charge state monoisotopic peaks of $\mathrm{A} \beta$ monomer were monitored while moving the emitter horizontally across the entrance ${ }^{\circ}$ aperture.$^{\circ}$ Results $^{\circ}$ are $^{\circ}$ shown $^{\circ}$ in ${ }^{\circ}$ Figure $^{\circ} 6 .^{\circ}$ The profile for the coaxial probe was obtained while running $0.5-\mu \mathrm{M} \mathrm{A} \beta$ monomer in $50 / 50 / 0.5(\mathrm{vol} / \mathrm{vol} / \mathrm{vol})$ $\mathrm{H}_{2} \mathrm{O} / \mathrm{MeCN} / \mathrm{HCOOH}$ at $10 \mu \mathrm{L} / \mathrm{min}$ in tube 1 . The results for the triaxial probe were generated by running $1-\mu \mathrm{M} \mathrm{A} \beta$ monomer in $100 / 0.5$ (vol/vol) $\mathrm{H}_{2} \mathrm{O} / \mathrm{HCOOH}$ at $5 \mu \mathrm{L} / \mathrm{min}$ in tube 1 and $100 / 0.5$ ( vol/vol) MeCN/ $\mathrm{HCOOH} 100 / 0.5 \mathrm{H}_{2} \mathrm{O} / \mathrm{HCOOH}$ at $5 \mu \mathrm{L} / \mathrm{min}$ in tube 2, giving the same final composition and total flow. The two curves show similar trends. The fact that the biggest ratios were obtained when the probe tip was farthest away from the orifice is consistent with space charge, which would preferentially repel more highly charged ions to the periphery of the electrospray. Also plotted $^{\circ}$ in $^{\circ}$ Figure $^{\circ} 6^{\circ}$ are $^{\circ}$ the ${ }^{\circ}$ ratios $^{\circ}$ obtained $^{\circ}$ when ${ }^{\circ}$ the premixed solution was run through both tube 1 and tube 2 of the triaxial probe ( $5 \mu \mathrm{L} / \mathrm{min}$ in each tube). The curve is indistinguishable from that obtained using the separated solvents, suggesting little (if any) effect of imperfect mixing which could have affected the solvent dielectric and therefore the charge-state distribution [39]. ${ }^{\circ} \mathrm{We}^{\circ}$ conclude $^{\circ}$ that ${ }^{\circ}$ space $^{\circ}$ charge $^{\circ}$ and $^{\circ}{ }^{\circ}$ resulting ${ }^{\circ}$ ion sampling effects are the primary contributors to the small $^{\circ}$ differences $^{\circ}$ evident $^{\circ}$ in $^{\circ}$ Figure $^{\circ} 5$. $^{\circ}$ The $^{\circ}$ higher ${ }^{\circ}$ currents for the coaxial probe may result in higher space charge, and therefore more scattering and less efficient sampling ${ }^{\circ}{ }^{\circ}{ }^{\circ}$ more $^{\circ}$ highly $^{\circ}{ }^{\circ h a r g e d}{ }^{\circ}{ }^{i o n s}{ }^{\circ}[37]$.

\section{Mixing}

Because of the rapid kinetics of proton exchange of reasonably strong acids and bases, the protonation/ deuteration of triethylamine (TEA) was used as a probe of mixing efficiency. To mimic the flow conditions used above, $10 / 90$ ( $\mathrm{vol} / \mathrm{vol}$ ) $\mathrm{D}_{2} \mathrm{O} / \mathrm{MeCN}$ was pumped at $5.1 \mu \mathrm{L} / \mathrm{min}$ through tube 2 , while $0.1 \mu \mathrm{M}$ TEA in $100 / 0.5 \mathrm{H}_{2} \mathrm{O} / \mathrm{HCOOH}$ was delivered to both arms of $\mathrm{T} 1$ (flow rates of $0.85 \mu \mathrm{L} / \mathrm{min}$ and 4.25 $\mu \mathrm{L} / \mathrm{min}$ ), and then to tube 1 (total $\mathrm{H}_{2} \mathrm{O}$ flow rate 5.1 $\mu \mathrm{L} / \mathrm{min}$ ). If the mixing at the sprayer tip is $100 \%$ efficient, the $[\text { TEA }+\mathrm{D}]^{+}:[\text {TEA }+\mathrm{H}]^{+}$ratio would be $1: 10$, so that the signal intensity at $m / z 103$ would be $\sim 16.8 \%$ of that at $\mathrm{m} / \mathrm{z} 102$ (including contributions from $\mathrm{D},{ }^{13} \mathrm{C}$, and ${ }^{14} \mathrm{~N}$ ). If there is no mixing at all at the sprayer tip, there would be no excess [TEA $+\mathrm{D}]^{+}$and the signal at $\mathrm{m} / \mathrm{z} 103$ would be just $6.8 \%$ of that at $\mathrm{m} / \mathrm{z}$ 102 , reflecting the normal isotopic abundance. Experimentally, the measured ratio was $14.8 \% \pm 0.3 \%$, suggesting a mixing efficiency of roughly $80 \% \pm 3 \%$ [(14.8-6.8)/(16.8-6.8); the ${ }^{13} \mathrm{C}$ and ${ }^{14} \mathrm{~N}$ contributions are subtracted]. This in turn would provide $36 \% \pm 1 \%$ $\mathrm{MeCN}$ in the "final" mix, instead of the expected $45 \%$. By contrast, when the solutions were premixed 1:1 and run through all tubes at the indicated flow rates, the experimental ratio was $17.1 \% \pm 0.2 \%$, very close to the theoretical prediction. The mixing efficiency at T1 was tested separately using the coaxial probe. In this case, $0.1 \mu \mathrm{M}$ TEA in $\mathrm{D}_{2} \mathrm{O}(0.85 \mu \mathrm{L} / \mathrm{min})$ was mixed with 46/54/0.5 (vol/vol/vol) $\mathrm{H}_{2} \mathrm{O} / \mathrm{MeCN}$ $/ \mathrm{HCOOH}(9.25 \mu \mathrm{L} / \mathrm{min})$ in $\mathrm{T} 1$, and then the whole mixture was delivered and sprayed through tube 1 . The measured $\mathrm{i}_{103} / \mathrm{i}_{102}$ ratio was $26.8 \% \pm 1.0 \%$, matching the expected value of $\sim 26.8 \%$ for perfect mixing, indicating that the mixing efficiency in T1 is $\sim 100 \%$ within the experimental error. For comparison, a value of $27.5 \% \pm 0.7 \%$ was obtained from a 0.85:9.25 premixed solution, also within the experimental error of the expected value. These mixing efficiencies should be interpreted as maximum values, since they are based on the mixing of water, protons and the small TEA molecule; slower diffusion or increased viscosity in solutions of a larger molecule like $\mathrm{A} \beta$ might result in less homogeneity. Nevertheless, clearly mixing at the emitter tip for the triaxial probe is reasonable, though not perfect. 
Table 2. Comparison of on-line solubility of fibrils in the mixing ${ }^{\circ}$ tee ${ }^{\circ}\left(\mathrm{T}^{\circ}{ }^{\circ}{ }^{\circ}{ }^{\circ} \text { Figure }^{\circ} 1\right)^{\circ}$ using $^{\circ}$ the ${ }^{\circ}$ triaxial ${ }^{\circ}$ probe ${ }^{\circ}$ and ${ }^{\circ}$ the coaxial probe

\begin{tabular}{|c|c|c|}
\hline \multirow{2}{*}{$\begin{array}{l}\text { Initial fibril } \\
\text { concentration } \\
\text { in } 2 \mathrm{mM} \text { tris } \\
\text { buffer }\end{array}$} & \multicolumn{2}{|c|}{ Measured concentration $^{\mathrm{b}}(\% \text { dissolved })^{\mathrm{c}}$} \\
\hline & Triaxial probe & Coaxial probe \\
\hline $8.0 \mu \mathrm{M}$ & $7.3 \pm 0.9(91 \pm 11)$ & $7.9 \pm 0.7(99 \pm 8)$ \\
\hline $14.0 \mu \mathrm{M}$ & $11 \pm 1(81 \pm 9)$ & $12 \pm 1(89 \pm 9)$ \\
\hline $29.6 \mu \mathrm{M}$ & $12.6 \pm 0.5(43 \pm 2)$ & $16.0 \pm 1.5(54 \pm 5)$ \\
\hline
\end{tabular}

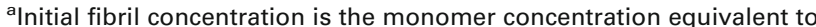
the fibrils suspended in $2 \mathrm{mM}$ tris buffer flowing into one arm of T1 (Figure 1).

${ }^{b}$ Measured concentrations are based on MS intensities.

c\% dissolved is the ratio of the measured concentration to the initial fibril concentration. The indicated uncertainties are standard deviations based on triplicate acquisitions of mass spectra.

\section{Fibril Dissolution}

Rapid disaggregation/dissolution of fibrils into monomers is essential for HDX-MS studies of fibrillar structure. Earlier studies found that more than half of the fibrils present in suspensions with $\sim 11 \mu \mathrm{M}$ equivalent monomer concentration could be dissolved in $<10 \mathrm{~s}$ using the coaxial $^{\circ}$ probe $^{\circ}[17] .{ }^{\circ}$ Studies ${ }^{\circ}$ of $^{\circ}$ the ${ }^{\circ}$ kinetics $^{\circ}$ of ${ }^{\circ}$ deuteration and parallel work with NMR suggest that the dissolved fraction represents full dissolution of a representative fraction of all fibrils, rather than sampling a readily dissolved fraction $^{\circ}$ of $^{\circ}$ each fibril $^{\circ}$ or $^{\circ}$ s subset $^{\circ}$ of fibrils 917,18 , 40]..$^{\circ} \mathrm{To}^{\circ} \mathrm{compare}^{\circ}$ the ${ }^{\circ}$ dissolution ${ }^{\circ}$ efficiency ${ }^{\circ}$ achieved $^{\circ}$ with the coaxial and triaxial probes, the intensities from on-line dissolution of fibril suspensions of varying effective monomer concentrations were compared with those obtained from monomer calibration curves (5 to $42 \mu \mathrm{M}$ monomer flowing into one arm of $\mathrm{T} 1$ at $0.85 \mu \mathrm{L} / \mathrm{min}$ for both probes). To improve precision, neurotensin was incorporated as an internal standard in the processing solvent (0.23 $\mu \mathrm{M}$ in 46/54/0.5 (vol/vol/vol) $\mathrm{H}_{2} \mathrm{O} /$ $\mathrm{MeCN} / \mathrm{HCOOH}$ flowing at $9.25 \mu \mathrm{L} / \mathrm{min}$ for the coaxial probe and $0.5 \mu \mathrm{M}$ in $100 / 0.5$ (vol/vol) $\mathrm{H}_{2} \mathrm{O} / \mathrm{HCOOH}$ flowing at $4.25 \mu \mathrm{L} / \mathrm{min}$ for the triaxial probe). For the triaxial probe, $100 / 0.5$ (vol/vol) $\mathrm{MeCN} / \mathrm{HCOOH}$ at 5 $\mu \mathrm{L} / \mathrm{min}$ was introduced through T2 as usual. Quantitation was based on the ratio of the summed intensities of monoisotopic peaks from the observed charge states of $\mathrm{A} \beta$ $(+4$ to +7$)$ and neurotensin $(+2$ and +3$)$.

Table $^{\circ} 2^{\circ}$ summarizes $^{\circ}$ the $^{\circ}$ results $^{\circ}$ of ${ }^{\circ}$ this $^{\circ}$ study..$^{\circ}$ The measured monomer concentration increases monotonically with increasing fibril load, suggesting that saturation (equilibration) is not achieved. At monomer equivalent concentrations of $\sim 8 \mu \mathrm{M}$ or $\sim 14 \mu \mathrm{M}$, the dissolution of the fibrils with either probe is efficient, but the coaxial probe is slightly more efficient than the triaxial probe. At $\sim 30 \mu \mathrm{M}$, neither probe is efficient, and the difference is somewhat bigger. The decrease in dissolution efficiency (reflected as \% dissolution) with increasing fibril concentration confirms kinetics control, with slower dissolution and faster redeposition at higher fibril loads. Even though different loadings of
A $\beta$ fibrils demonstrate different solubility on the two probes, preliminary results from HDX-MS studies of $\mathrm{A} \beta$ fibrils at different equivalent concentrations (13 $\mu \mathrm{M}$, $18 \mu \mathrm{M}$ and $28 \mu \mathrm{M})$ using the triaxial probe gave rise to similar deuteration levels in the same time frame, indicating the preservation of the core structure at the concentrations studied (details to be reported in a subsequent publication).

To ascertain whether the evident poorer dissolution efficiency of the triaxial probe is related to the incomplete mixing described above and/or to the shorter exposure to $\mathrm{MeCN}$, a series of experiments was undertaken to assess the dependence of fibril dissolution on the concentration of $\mathrm{MeCN}$. For these experiments, 300 $\mu \mathrm{L}$ fibrillar suspensions were prepared with equivalent monomer concentration of $2.0 \mu \mathrm{M}, 0.5 \%$ formic acid, 0.2 $\mathrm{mM}$ tris, and $\mathrm{MeCN}$ concentrations of $0,15,30,45,60$, or $90 \%$ (vol/vol). Each suspension was centrifuged and decanted $2 \mathrm{~h}$ after mixing, and the monomer concentration in $100-\mu \mathrm{L}$ aliquots of the supernatants was determined using HPLC/UV. The fibrils were then resuspended by shaking in a vortex mixer for $1 \mathrm{~min}$. Centrifugation and LC measurements were then repeated $22 \%$ later. ${ }^{\circ}$ As ${ }^{\circ}$ evident ${ }^{\circ}$ in ${ }^{\circ}$ Figure $\%$, fibril ${ }^{\circ}$ solubility in $90 \% \mathrm{MeCN}$ was negligible. Otherwise, dissolution was enhanced whenever both $\mathrm{MeCN}$ and water were present, with essentially complete dissolution after $24 \mathrm{~h}$ in $30 \% \mathrm{MeCN}$. In contrast, the solution with no MeCN achieved only about $47 \%$ dissolution after $2 \mathrm{~h}$, and solubility did not increase after an additional $22 \mathrm{~h}$; this sample apparently reached its equilibration concentration within the first $2 \mathrm{~h}$ (although further dissolution may have occurred after an even longer incubation time). ${ }^{\circ}$ Comparison $^{\circ}$ of $^{\circ}$ data $^{\circ}$ from $^{\circ}$ Figure $^{\circ} 7^{\circ}$ and $^{\circ}$ Table $^{\circ} 2$ suggests that fibrils may equilibrate in the aqueous solution with no $\mathrm{MeCN}$ even within the short mixing time ${ }^{\circ}$ in $^{\circ}$ the ${ }^{\circ}$ triaxial ${ }^{\circ}$ probe $^{\circ}$ Table $^{\circ} 2^{\circ}$ shows ${ }^{\circ} 43 \%{ }^{\circ}$ dissolution of $29.6 \mu \mathrm{M}$ (initial equivalent) fibrils in the triaxial

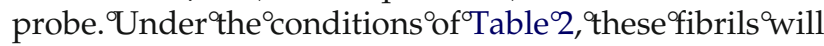

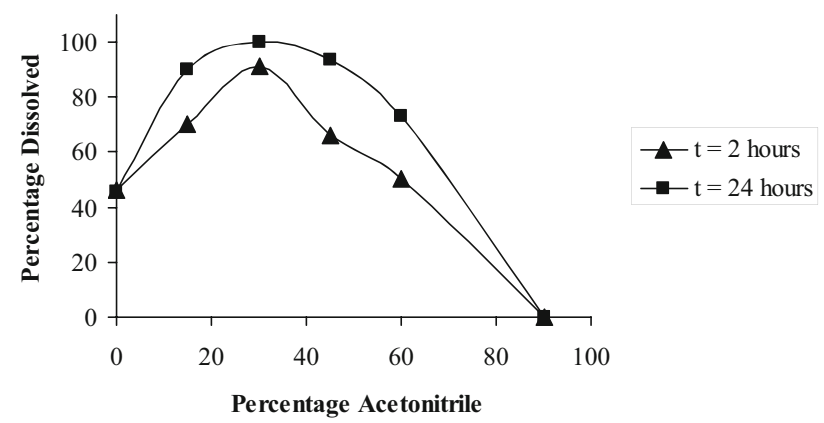

Figure 7. Effects of acetonitrile on the solubility of 2- $\mu \mathrm{M}$ (monomer equivalent concentration) $\mathrm{A} \beta$ fibrils ( $2 \mathrm{~h}$ and $24 \mathrm{~h}$ incubation). The solvent mixture contains $0.5 \%$ formic acid, $0.2 \mathrm{mM}$ tris and the indicated percentage of acetonitrile (balance water). The concentration of acetonitrile-water-formic acid mixtures is reported as percentage volume-volume (vol/vol). "Percentage Dissolved" is the ratio of dissolved $A \beta$ (based on HPLC/UV measurements on the supernatant) to total $\mathrm{A} \beta$ (monomer equivalent) in the starting solution. 
have been diluted to $\sim 6 \mu \mathrm{M}$ with $100 / 0.5$ (vol/vol) $\mathrm{H}_{2} \mathrm{O} / \mathrm{HCOOH}$ for about $12 \mathrm{~s}$, followed by further dilution to $\sim 3 \mu \mathrm{M}$ with $\mathrm{MeCN}$ for the last $1.1 \mathrm{~s}$ at the probe tip. Although the final MeCN concentration was $41 \%$, the $43 \%$ dissolution more closely resembles that for ${ }^{\circ}$ the ${ }^{\circ}$ pure $^{\circ}$ aqueous $^{\circ}$ solution ${ }^{\circ}$ in $^{\circ}$ Figure $^{\circ} 7^{\circ}\left(47 \%\right.$, ${ }^{\circ}$ versus $>60 \%$ at $45 \% \mathrm{MeCN})$. The imperfect mixing described above is unlikely to cause such a large effect, given the relatively weak dependence of solubility on $\mathrm{MeCN}$ concentration ${ }^{\circ}$ around $41 \%$ in ${ }^{\circ}$ Figure $\%$; the triaxial ${ }^{\circ}$ probe evidently does not allow adequate mixing time to realize the full enhancement of dissolution afforded by $\mathrm{MeCN}$. More complete fibril dissolution might be obtained by using slower flow rates (longer time), but this would lead to increased exposure to back-exchange and therefore to loss of structural information. Use of relatively low fibril concentrations to assure good dissolution appears to be a reasonable compromise.

\section{Artifactual Exchange}

As noted above, postincubation sample processing steps involving protic solvents can introduce artifactual exchange in HDX-MS, adding to (forward exchange, $\mathrm{FE}$ ) or removing (back-exchange, $\mathrm{BE}$ ) the deuterium incorporated during incubation in $\mathrm{D}_{2} \mathrm{O}$. While methods exist to correct for these artifacts when calculating total deuterium ${ }^{\circ}$ incorporation ${ }^{\circ}\left[8,{ }^{\circ} 22\right],{ }^{\circ}$ assessment ${ }^{\circ}$ of $^{\circ}$ the ${ }^{\circ}$ extent of exchange and especially localization of exchange (e.g., by MS/MS) will be more reliable if artifactual exchange ${ }^{\circ} \operatorname{can}^{\circ} \mathrm{be}^{\circ} \operatorname{minimized}^{\circ}\left[8,{ }^{\circ} 18\right] .{ }^{\circ} \mathrm{Such}^{\circ}{ }^{\circ}$ inimization contributed to the choice of $\mathrm{MeCN}$ as a nonprotic cosolvent ${ }^{\circ}$ in $^{\circ}$ earlier $^{\circ}$ studies $^{\circ}\left[17,{ }^{\circ} 18\right],{ }^{\circ}$ reducing ${ }^{\circ}$ the ${ }^{\circ}$ effective concentrations of $\mathrm{H}_{2} \mathrm{O}$ and $\mathrm{D}_{2} \mathrm{O}$ while facilitating electrospray. This proved to be effective with the coaxial $^{\circ}$ probe $^{\circ}\left[17,{ }^{\circ} 18\right] ;{ }^{\circ}$ artifactual ${ }^{\circ}$ exchange $^{\circ}$ was $^{\circ}$ within $^{\circ}$ the range $^{\circ}$ reported $^{\circ}$ elsewhere $^{\circ}$ using $^{\circ}$ other $^{\circ}$ methods $^{\circ}$ [18]. However, effectiveness might be compromised by delayed introduction of $\mathrm{MeCN}$ and incomplete mixing. Thus, as a final measure of the utility of the triaxial probe for HDX-MS studies, the extent of artifactual exchange was assessed and compared with that using the coaxial probe.

$\mathrm{A} \beta$ monomers were chosen as probes for these tests because they represent a "worst-case scenario"; their exposure to artifactual exchange is not mitigated by slow dissolution, as is the case for fibrils. FE was assessed by mixing a $25 \mu \mathrm{M}$ aqueous solution of monomer in $2 \mathrm{mM}$ tris $(0.85 \mu \mathrm{L} / \mathrm{min})$ with processing solvent (80/20/0.5 (vol/vol/vol) $\mathrm{H}_{2} \mathrm{O} / \mathrm{D}_{2} \mathrm{O} / \mathrm{HCOOH}$ at 4.25 $\mu \mathrm{L} / \mathrm{min}$ in $\mathrm{T} 1$ followed by addition of $\mathrm{MeCN}$ at 5 $\mu \mathrm{L} / \mathrm{min}$ via tube 2 for the triaxial probe; 36.8/9.2/54/ 0.5 ( $\mathrm{vol} / \mathrm{vol} / \mathrm{vol} / \mathrm{vol}) \mathrm{H}_{2} \mathrm{O} / \mathrm{D}_{2} \mathrm{O} / \mathrm{MeCN} / \mathrm{HCOOH}$ at $9.25 \mu \mathrm{L} / \mathrm{min}$ in $\mathrm{T} 1$ for the coaxial probe) chosen to generate a final solution in which $16.7 \%$ of the water was $\mathrm{D}_{2} \mathrm{O}$. For assessment of BE, $25 \mu \mathrm{M}$ fully deuterated monomer in $2 \mathrm{mM}$ fully deuterated tris $(0.85 \mu \mathrm{L} / \mathrm{min})$ was mixed in $\mathrm{T} 1$ with an $\mathrm{H}_{2} \mathrm{O}$-based processing solvent (100/0.5 (vol/vol) $\mathrm{H}_{2} \mathrm{O} / \mathrm{HCOOH}$ at $4.25 \mu \mathrm{L} / \mathrm{min}$ fol- lowed by $100 / 0.5$ (vol/vol) $\mathrm{MeCN} / \mathrm{HCOOH}$ in T2 for the triaxial probe; 46/54/0.5 (vol/vol/vol) $\mathrm{H}_{2} \mathrm{O} /$ $\mathrm{MeCN} / \mathrm{HCOOH}$ at $9.25 \mu \mathrm{L} / \mathrm{min}$ for the coaxial probe), which again gave a final solution in which $16.7 \%$ of the water was $\mathrm{D}_{2} \mathrm{O}$. Such analyses represent standard steps in obtaining ${ }^{\circ}$ data $^{\circ}$ for $^{\circ}$ correction $^{\circ}$ of ${ }^{\circ}$ artifactual $^{\circ}$ exchange $^{\circ}[18]$. As in previous studies, labile side-chain, terminal, and ionizing protons are assumed to be statistically labeled; their contribution was subtracted to allow assessment of $\mathrm{BE}^{\circ}$ and ${ }^{\circ} \mathrm{FE}^{\circ}$ relevant ${ }^{\circ}$ to ${ }^{\circ}$ backbone ${ }^{\circ}$ amides $^{\circ}[18]$.

Results show that BE was $6.5 \pm 0.05$ (D replaced by $\mathrm{H})$ and $\mathrm{FE}$ was $1.5 \pm 0.03$ (H exchanged for $\mathrm{D})$ using the coaxial probe, while the numbers are slightly higher with the triaxial probe (BE: $6.8 \pm 0.1$; FE: $2.0 \pm 0.03$ ), probably reflecting the slightly longer mixing time (13.1 versus $12 \mathrm{~s}$ for the coaxial probe) and the higher effective water concentration due to imperfect mixing. In both cases, the difference is less than one exchanged proton/deuterium, well within the uncertainty with which total exchange is usually determined. $\mathrm{BE}$ exceeds $\mathrm{FE}$, reflecting the fact that $\mathrm{H}_{2} \mathrm{O}$ (rather than $\mathrm{D}_{2} \mathrm{O}$ ) is the primary water component $(83.3 \%)$ after mixing.

\section{Conclusions}

The triaxial probe represents a classic compromise in trying to optimize independent processes. While its performance in terms of signal stability, artifactual exchange, and fibril dissolution does not match that of the standard coaxial probe, the differences are relatively small, especially when compared with the major enhancement in the effectiveness of on-line proteolysis. By decoupling reaction and spray optimization, the probe may enable a wide range of on-line reactions to facilitate system characterization in HDX-MS and other applications. Performance with respect to the other figures of merit in other applications may be improved by reoptimizing flow rates and tube diameters. However, modifications to increase enzyme reaction time (e.g., lengthening tube 2) must be traded against increased artifactual exchange in HDX experiments. Studying faster kinetics (e.g., the initial moments of the HDX reaction) might be feasible by adapting the HDX steps to continuous flow with monitoring from the moment of fibril suspension in $\mathrm{D}_{2} \mathrm{O}$. For our purposes, it is usually the plateau achieved at longer times that is of interest, so continuous flow analysis of incubating fibrils was not attempted. Using discrete sampling of an incubating fibril suspension, we have been able to monitor the kinetics of HDX beginning after about 8 $\min ^{\circ}$ of $^{\circ}$ incubation ${ }^{\circ}[17-19]$.

\section{Acknowledgments}

This work was supported in part by the National Institutes of Health (grant no. R01-AG18927) and the National Science Foundation (grant no. CHE-0130752). Special thanks are given to Angela D. Williams for providing some of the $\mathrm{A} \beta$ samples and to 


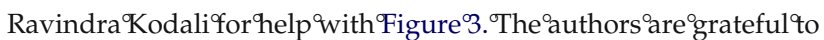
Dr. Albert A. Tuinman for helpful discussions.

\section{References}

1. Englander, S. W.; Kallenbach, N. R. Hydrogen Exchange and Structural Dynamics of Proteins and Nucleic Acids. Q. Rev. Biophys. 1983, 16, 521-655.

2. Dempsey, C. E. Hydrogen Exchange in Peptides and Proteins Using NMR Spectroscopy. Prog. Nucl. Magn. Reson. Spectrosc. 2001, 39, 135170

3. Heimburg, T.; Marsh, D. Investigation of Secondary and Tertiary Structural Changes of Cytochrome $c$ in Complexes with Anionic Lipids Using Amide Hydrogen Exchange Measurements: An FTIR Study. Biophys. J. 1993, 65, 2408-2417.

4. Baello, B. I.; Pancoska, P.; Keiderling, T. A. Enhanced Prediction Accuracy of Protein Secondary Structure Using Hydrogen Exchange Fourier Transform Infrared Spectroscopy. Anal. Biochem. 2000, 280, $46-57$.

5. Anderegg, R. J. Using Deuterium Exchange and Mass Spectrometry to Study Protein Structure. In Mass Spectrometry in the Biological Sciences; Burlingame, A. L.; Carr, S. A., Eds.; Humana: Totowa, 1996; p 85.

6. Smith, D. L.; Deng, Y.; Zhang, Z. Probing the Noncovalent Structure of Proteins by Amide Hydrogen Exchange and Mass Spectrometry. J. Mass Spectrom. 1997, 32, 135-146.

7. Eyles, S. J.; Kaltashov, I. A. Methods to Study Protein Dynamics and Folding by Mass Spectrometry. Methods 2004, 34, 88-99.

8. Zhang, Z.; Smith, D. L. Determination of Amide Hydrogen Exchange by Mass Spectrometry: A New Tool for Protein Structure Elucidation. Protein Sci. 1993, 2, 522-531.

9. Miranker, A.; Robinson, C. V.; Radford, S. E.; Dobson, C. M. Investigation of Protein Folding by Mass Spectrometry. FASEB J. 1996, 10, 93-101.

10. Zubarev, R. A.; Kelleher, N. L.; McLafferty, F. W. Electron Capture Dissociation of Multiply Charged Protein Cations. A Nonergodic Process. J. Am. Chem. Soc. 1998, 120(13), 3265-3266.

11. Hoerner, J. K.; Xiao, H.; Dobo, A.; Kaltashov, I. A. Is There Hydrogen Scrambling in the Gas Phase? Energetic and Structural Determinants of Proton Mobility within Protein Ions. J. Am. Chem. Soc. 2004, 126, 7709-7717.

12. Jorgensen, T. J.; Gardsvoll, H.; Ploug, M.; Roepstorff, P. Intramolecular Migration of Amide Hydrogens in Protonated Peptides Upon Collisional Activation. J. Am. Chem. Soc. 2005, 127, 2785-2793.

13. Kweon, H. K.; Hakansson, K. Site-Specific Amide Hydrogen Exchange in Melittin Probed by Electron Capture Dissociation Fourier Transform Ion Cyclotron Resonance Mass Spectrometry. Analyst (Cambridge, UK) 2006, 131, 275-280.

14. Wang, L.; Pan, H.; Smith, D. L. Hydrogen Exchange-Mass Spectrometry: Optimization of Digestion Conditions. Mol. Cell. Proteom. 2002, 1(2), 132-138

15. Ehring, H. Hydrogen Exchange/Electrospray Ionization Mass Spectrometry Studies of Structural Features of Proteins and Protein/Protein Interactions. Anal. Biochem. 1999, 267, 252-259.

16. Woods, V. L. A Deuterium Exchange-Mass Spectrometry Analysis Using Endopeptidase Fragmentation for High-Resolution Identification of Solvent-Accessible Amide Hydrogens in Proteins and for Characterization of Protein Structure. PCT Int. Appl. 2003, 134.

17. Kheterpal, I.; Zhou, S.; Cook, K. D.; Wetzel, R. A $\beta$ Amyloid Fibrils Possess a Core Structure Highly Resistant to Hydrogen Exchange. Proc. Natl. Acad. Sci. U.S.A. 2000, 97, 13597-601.

18. Kheterpal, I.; Wetzel, R.; Cook, K. Enhanced Correction Methods for Hydrogen Exchange-Mass Spectrometric Studies of Amyloid Fibrils. Protein Sci. 2003, 12, 635-643.
19. Kheterpal, I.; Wetzel, R.; Cook, K. Hydrogen/Deuterium Exchange Mass Spectrometry Analysis of Protein Aggregates. Methods Enzymol. 2006, 413, 140-166.

20. Simon, L. M.; Laszlo, K.; Vertesi, A.; Bagi, K.; Szajani, B. Stability of Hydrolytic Enzymes in Water-Organic Solvent Systems. J. Mol. Catal. B Enzym. 1998, 4, 41-45.

21. Russell, W. K.; Park, Z. Y.; Russell, D. H. Proteolysis in Mixed OrganicAqueous Solvent Systems: Applications for Peptide Mass Mapping Using Mass Spectrometry. Anal. Chem. 2001, 73, 2682-2685.

22. Cech, N. B.; Enke, C. G. Practical Implications of Some Recent Studies in Electrospray Ionization Fundamentals. Mass Spectrom. Rev. 2001, 20, 362-387.

23. Inouye, K.; Fruton, J. S. Studies on the Specificity of Pepsin. Biochem. $1967,6,1765-1777$

24. Dunn, B. M.; Fink, A. L. Cryoenzymology of Porcine Pepsin. Biochemistry 1984, 23, 5241-5247.

25. Edelhoch, H. Denaturation of Pepsin III. Effects of Various Protein Denaturants on the Kinetics of Pepsin Inactivation. J. Am. Chem. Soc. 1958, 80, 6648-6655.

26. Klibanov, A. M. Why are Enzymes Less Active in Organic Solvents than in Water? Trends Biotechnol. 1997, 15, 97-101.

27. Powers, J. C.; Harley, A. D.; Myers, D. V. 1977; Subsite Specificity of Porcine Pepsin. In Acid Proteases, Structure, Function, and Biology; Tang, J, Ed.; Plenum Press: New York, 1977; p 141.

28. Ikonomou, M. G.; Blades, A. T.; Kebarle, P. Electrospray-Ion Spray: A Comparison of Mechanisms and Performance. Anal. Chem. 1991, 63(18), 1989-98.

29. Kostiainen, R.; Bruins, A. P. Effect of Solvent on Dynamic Range and Sensitivity in Pneumatically-Assisted Electrospray (Ion Spray) Mass Spectrometry. Rapid Commun. Mass Spectrom. 1996, 10(11), 1393-1399.

30. Williams, A. D.; Portelius, E.; Kheterpal, I.; Guo, J.-T.; Cook, K. D.; Xu, Y.; Wetzel, R. Mapping A $\beta$ Amyloid Fibril Secondary Structure Using Scanning Proline Mutagenesis. J. Mol. Biol. 2004, 335(3), 833-842.

31. Guo, J.-T.; Wetzel, R.; Xu, Y. Molecular Modeling of the Core of A $\beta$ Amyloid Fibrils. Proteins 2004, 57, 357-364

32. Williams, A. D.; Shivaprasad, S.; Wetzel, R. Alanine Scanning Mutagenesis of A $\beta$ (1-40) Amyloid Fibril Stability. J. Mol. Biol. 2006, 357(4), 1283-1294.

33. Van Berkel, G. J.; Zhou, F.; Aronson, J. T. Changes in Bulk Solution pH Caused by the Inherent Controlled-Current Electrolytic Process of an Electrospray Ion Source. Int. J. Mass Spectrom. Ion Processes 1997, 162(1/3), 55-67.

34. Konermann, L.; Silva, E. A.; Sogbein, O. F. Electrochemically Induced $\mathrm{pH}$ Changes Resulting in Protein Unfolding in the Ion Source of an Electrospray Mass Spectrometer. Anal. Chem. 2001, 73, 4836-4844.

35. Zhou, S.; Edwards, A. G.; Cook, K. D.; Van Berkel, G. J. Investigation of the Electrospray Plume by Laser-Induced Fluorescence Spectroscopy. Anal. Chem. 1999, 71, 769-776.

36. Wang, G.; Cole, R. B. Gas-phase and Instrumental Parameter Influences on Charge-state Distributions in Electrospray Ionization Mass Spectrometry. In Electrospray Ionization Mass Spectrometry. Cole, R.B., Ed., John Wiley \& Sons: New York, 1997; pp. 137-174.

37. Gale, D. C.; Smith, R. D. Small Volume and Low Flow-Rate Electrospray Ionization Mass Spectrometry of Aqueous Samples. Rapid Commun. Mass Spectrom. 1993, 7(11), 1017-21.

38. Ikonomou, M. G.; Blades, A. T.; Kebarle, P. Investigations of the Electrospray Interface for Liquid Chromatography/Mass Spectrometry. Anal. Chem. 1990, 62, 957-967.

39. Cole, R. B.; Harrata, A. K. Solvent Effect on Analyte Charge State, Signal Intensity, and Stability in Negative Ion Electrospray Mass Spectrometry; Implications for the Mechanism of Negative Ion Formation. J. Am. Soc. Mass Spectrom. 1993, 4(7), 546-556.

40. Whittemore, N. A.; Mishra, R.; Kheterpal, I.; Williams, A. D.; Wetzel, R. Serpersu, E. H. Hydrogen-Deuterium (H/D) Exchange Mapping of A $\beta$ (1-40) Amyloid Fibril Secondary Structure Using Nuclear Magnetic Resonance Spectroscopy. Biochemistry 2005, 44(11), 4434-4441. 